\title{
Evaluation of Occupational Health and Safety Management System (SMK3) Health Service Facilities at Puskesmas Cijagra Lama Bandung City
}

\author{
Enisah Enisah ${ }^{1}$; Arif Susanto ${ }^{2^{*}}$ ) \\ ${ }^{1}$ Pusat Kesehatan Masyarakat Cijagra Lama Bandung \\ ${ }^{2 *}$ Universitas Kebangsaan Republik Indonesia
}

\section{ARTICLE INFO}

Article history:

Received July 08, 2020

Accepted September 21, 2020

Published December 05, 2020

\section{Keyword:}

Evaluation

Health care facilities

OHS performances

Public health center OSHMS

\section{A B S T R A C T}

Health care facilities (fasyankes) are workplaces that pose risks to the safety and health of human resources (HR), patients or clients as well as their companions, visitors and the community living near the health facility. Occupational Health and Safety Management System (OHSMS) at the Community Health Center (Puskesmas) aims to efficient and continuously perform OHS at the health facilities. The purpose of this review is to evaluate the effectiveness and appropriateness of the implementation of the OHS management system, at health facilities so that they are sustainable in achieving the OHSMS goals. The method used is technical triangulation by participatory observation, in-depth interviews and document review. The results show that the Health Center of Cijagra Lama Bandung has an index of 0.8 or $80 \%$ that has fulfilled the requirements according to the Indonesian Minister of Health Regulation No. 52 year 2018 concerning Occupational Safety and Health in Health Care Facilities. Continuous improvement of OHS performance carried out for the elements of applying ergonomic principles for lifting; regular health medical check up; immunization for health workers at risk; maintenance of medical equipment; training and amount of health workers trained.

This open access article is under the CC-BY-SA license.

\section{Evaluasi Sistem Manajemen Keselamatan dan Kesehatan Kerja (SMK3) Fasyankes Di Puskesmas Cijagra Lama Kota Bandung}

\section{A B S T R A K}

Kata kunci:

Evaluasi

Fasyankes

Kinerja K3

Puskesmas

SMK3

\section{*) corresponding author}

Proram Studi Teknik Lingkungan, Fakultas Teknik Sipil dan Perencanaan Universitas Kebangsaan Republik Indonesia

Email: arifssnt@yahoo.com

DOI: https://doi.org/10.30604/jika.v5i2.327
Fasilitas pelayanan kesehatan (fasyankes) merupakan tempat kerja yang berisiko terhadap keselamatan dan kesehatan sumber daya manusia (SDM), pasien atau klien serta pendampingnya, pengujung dan masyarakat yang berada di sekitar lingkungan fasyankes. Sistem manajemen keselamatan dan kesehatan kerja (SMK3) di Pusat Kesehatan Masyarakat (Puskesmas) bertujuan untuk terselenggaranya K3 fasyankes secara optimal, efektif, efisien serta berkesinambungan. Tujuan peninjauan SMK3 ini dilakukan untuk mengevaluasi efektifitas dan kesesuaian penerapan SMK3 di fasyankes agar berkesinambungan untuk mencapai tujuan SMK3. Metode yang digunakan yaitu triangulasi teknik dengan melakukan observasi partisipatif, wawancara mendalam dan kajian dokumen. Hasil menunjukkan Puskesmas Cijagra Lama Bandung memiliki indeks sebesar 0,8 atau $80 \%$ telah memenuhi persyaratan sesuai Peraturan Menteri Kesehatan RI Indonesia Nomor 52 Tahun 2018 tentang Keselamatan dan Kesehatan Kerja di Fasilitas Pelayanan Kesehatan. Perbaikan dan peningkatan kinerja K3 yang berkelanjutan dapat dilakukan untuk elemen penerapan prinsip ergonomi untuk angkat-angkut; pemeriksaan kesehatan SDM secara berkala; imunisasi bagi SDM fasyankes yang berisiko; 
pemeliharaan pada peralatan medis; SDM fasyankes terlatih K3 dan jumlah SDM fasyankes yang terlatih K3.

This open access article is under the CC-BY-SA license.

\section{Introduction}

Health service facilities (fasyankes) in implementing health service efforts (yankes) are required to carry out occupational safety and health (K3). The implementation of OHS is carried out by implementing risk management and control related to OHS to create a healthy, safe, secure and comfortable health facility. The implementation of OHS at the health facility includes the establishment and/or development of a OHS management system (SMK3) accompanied by implementing OHS standards that are adjusted to the characteristics and risk factors (Ministry of Health of the Republic of Indonesia, 2018).

A health service facility is a place that is used for the implementation of health services efforts which consist of preventive, promotive, curative and rehabilitative efforts carried out by the government, local government (Pemda) and / or the community (Ministry of Health, 2019). The types of health facilities include the Public Health Center (Puskesmas). Public Health Center is the first level of health facilities which has a very important role in improving public health. The Public Health Center is the District / City Health Service Technical Implementation Unit (UPTD) which is responsible for carrying out health development in its working area. Public Health Centers are primary health facilities located in the vicinity of the community (Ministry of Health of the Republic of Indonesia, 2004).

The World Health Organization (WHO) in 2000 noted that infection cases caused by needle sticks contaminated with the virus are estimated to cause occupational diseases (PAK), namely Hepatitis B by $32 \%$, Hepatitis C by $40 \%$, and HIV by $5 \%$ of all new infections. The Panamerican Health Organization (PAHO) in 2017 estimated that 8-12\% of health care workers were sensitive to latex gloves. Data from the Directorate for Prevention and Control of Direct Communicable Diseases during 1987-2016 contained 178 medical personnel infected with HIV / AIDS. The results of the research on 108 health centers from 136 health facilities showed that almost all Public Health Center officers did not understand and know about standard precautions. In addition to the occurrence of PAK, a number of cases of work accidents (KK) that were fatal at health facilities have also occurred, including electric shocks, fires, floods, collapsed buildings due to earthquakes, and deaths of health workers due to carbon monoxide (CO) poisoning ( Ministry of Health of the Republic of Indonesia, 2018).

Public Health Center at Cijagra Lama Bandung is a health facility that has implemented an accreditation mechanism. Public Health Center managers are obliged to make all forms of health efforts through efforts to prevent and treat disease, improve and restore health for workers, as well as so that workers can be protected and live healthy and free from health problems and bad effects caused by work. This is done to ensure that quality improvement, performance improvement and risk management implementation are carried out continuously by implementing SMK3 because it has risks to OHS.

Data in 2019, there were households in the form of needle sticks that occurred 5 times, although no PAK occurred at the Public Health Center Cijagra Lama Bandung (Bandung City Health Office, 2019). However, the potential dangers of OHS in this health facility still exist. This potential can include physical, chemical, biological, ergonomic, psychosocial and family hazards. Potential biological hazards of transmission of diseases such as viruses, bacteria, fungi, protozoa, parasites are the highest occupational health risks (kesja) for health facilities because they can cause PAK. In addition, the use of various medical devices (medical equipment) and technology at health facilities as well as the conditions of facilities and infrastructure that do not meet safety standards will pose a risk of KK from mild to fatal (Indonesian Ministry of Health, 2018). The purpose of this study is to assess the performance of OHS whether it is appropriate as part of the quality of health services including patient safety and health workers which must be guaranteed so that performance improvements can be carried out continuously and ensure that the health services provided are in accordance with the laws of the Republic of Indonesia.

\section{Method}

This study used a technical triangulation method, namely by using different data collection techniques to obtain data from the same source. The use of participatory observation, in-depth interviews, and documentation review which is carried out simultaneously (Sugiyono, 2011).

The data source in this study is the implementation performance of OHS health facilities in 2019. The location of the research was conducted at the Public Health Center Cijagra Lama Bandung, which is located at Jalan Buahbatu No. 375, Turangga Village, Lengkong District, Bandung City, West Java 40265.

The research was conducted from January to June 2020. The instruments used in this study were interview guidelines, semester report checklists and OHS annual reports at health facilities. Interviews were carried out to all human resources of the Public Health Center Cijagra Lama Bandung starting from the leadership to the workers at the health facility. The OHS semester and annual report checklists use sample reports in accordance with the provisions of the Minister Health Regulation (Permenkes) of the Indonesia Republic Number 52 of 2018 in Chapter III Recording and Reporting.

\section{Results and Discussion}

Public Health Center Cijagra Lama Bandung is a health facility that has plenary accreditation given by the Independent Institution which organizes Accreditation and is determined by the Health Ministry. The purpose of this accreditation is that the Puskesmas can perform its functions optimally. In carrying out this function, it is necessary to have a good Public Health Center organizational management. Generally, accreditation of Public Health 
Center can significantly influence performance improvement and achievement of service indicators so that Public Health Center must provide quality health services. Furthermore, for ensuring the quality of health services including OHS, health workers can be guaranteed (Wijayantiningrum, 2019).

The implementation of OHS in Public Health Center is included in the quality instrument. These instruments are part of the clinical quality management structure. The steps in implementing OHS include planning, implementing and evaluating as well as paying attention to the aspects of the indicators that must be met. This step is contained in the OHS service guidelines. The OHS strategy was developed in an integrated and comprehensive manner in the pattern of the health centre. This strategy is carried out through the plenary health service, which includes efforts to improve health, prevention of PAK, cure disease and health restoration. The increase in OHS is carried out through the active participation of the community, especially the working community (Suma'mur, 1986). The management of OHS at the health facility aims to hold OHS at the Public Health Center Cijagra Lama in Bandung through the implementation of SMK3.

Table 1

Recording and Reporting of OHS Implementation at the Public Health Center Bandung

\begin{tabular}{lc}
\hline Description & Total \\
\hline Number of HR & 29 \\
\hline Number of sick HR & 0 \\
\hline Number of common disease cases in HR & 0 \\
\hline The number of cases of suspected PAK to HR & 0 \\
\hline The number of PAK cases in HR & 0 \\
\hline Number of KK in HR & 2 \\
\hline Number of near miss cases in HR & 5 \\
\hline Number of days absent HR due to illness & 0 \\
\hline
\end{tabular}

SMK3 at Public Health Center is part of the overall health care management system. The management system is in order to control risks related to work process activities which include:

1. Determination of OHS policy

This OHS policy is made by the Head of the Puskesmas, then the OHS policy is socialized to all Puskesmas employees.

2. OHS planning

Public Health Center planning is made based on OHS risk management, laws and regulations and other requirements.

3. Implementation of the OHS plan

The implementation of the Public health and safety plan is supported by adequate resources.

4. OHS performance monitoring and evaluation

Monitoring and evaluation of Public Health Center OHS performance is carried out through examination, testing, measurement, and / or SMK3 internal audit.

5. OHS performance review and improvement

Table 1 illustrates the number of human resources working at the Public Health Center Cijagra Lama Bandung, totaling 29 personnel. Details of the task force for each person in accordance with the organizational structure which refers to the PerMenKes No. 75 in 2014, and is depicted in Figure 1 below. In 2019, there were no records and no reports of sick human resources, so there were no cases of health workers at the Public Health Center Cijagra
Lama Bandung Community who suffered from general illnesses, suspected cases of PAK or PAK cases among HR also did not exist. Thus, the number of days absent due to illness is also absent or zero days.

The number of KK in HR was 2 (two) KK incidents, in the form of needlestick incidents and door hitting. The factors causing the KK at the Public Health Centre Cijagra Lama Bandung were among others caused by the actions and actions of health workers who did not complete safety standards (unsafe human acts). The KK incident occurs due to human error because about 80 to $85 \%$ of accidents are caused by human negligence or error (human error). This matters directly or indirectly state that all accidents are caused by all humans because humans are involved in an activity. One of the precautions carried out by the Cijagra Lama Puskesmas to prevent KK is to ensure that when handling patients in the form of actions that involve syringes, namely according to standard operating procedures (SPO) as administrative control and the use of personal protective equipment (PPE) in the form of gloves (hand gloves) according to KK (work accident) control hierarchy.

The case number of near-miss in the HR of the Public Health Center Cijagra Lama were reported and recorded as many as 5 (five) incidents. These types of nearmiss are:

1. nearly slipped;

2. nearly crushed by glass;

3. nearly pricked by a syringe;

4. nearly mired in; and

5. nealy scratched the door on the arm.

Near-miss is caused by unsafe environmental conditions. Near-miss is an unexpected or unplanned event (unplanned event) that does not result in damage or injury but has the potential to lead to injury. Generally, this near-miss incident is purely due to human error. The unsafe conditions include the slippery floor condition after the wet cleaning process on the floor; conditions when there was a glass material lifting process during the building renovation process; floor conditions with different heights (uneven level) and conditions of doors made of glass or wood which have minor damage and have the potential to scratch someone's arm when closing or opening the door.

\section{SMK3 of Public Health Center Cijagra Lama Bandung}

The Minister of Manpower Regulation Number 05 / Men / 1996 states that the OHS Policy is a written statement signed by the entrepreneur and/or management which contains the overall vision and goals of the company, commitment and determination to implement policies, frameworks and work programs that cover the company;s overall activities in general and/or operational. This is also in accordance with Government Regulation (PP) RI Number 50 of 2012 concerning the Implementation of SMK3.

Based on the results of interviews with the head of the Public Health Center Cijagra Lama Bandung, regarding the commitment and policies of the Public Health Center leaders, it shows that the OHS policy has been made and has been implemented properly. The formulation of OHS policies has also been in accordance with Government Regulation Number 50 of 2012 which includes an initial review of OHS conditions, efforts to improve the performance of continuous OHS management and taking into account constructive input suggestions from all health workers working in the Puskesmas. 
The results of a document review regarding OHS policies, the Puskesmas Cijagra Lama Bandung has developed and developed procedures for implementing OHS in accordance with accreditation standards. The OHS policy as referred to includes the stipulation of policies and objectives of the health care health and safety program, the establishment of the health and health services organization and the determination of support in the form of funding, facilities and infrastructure. Socialization of health and safety policies for health facilities has been carried out to all health workers at the Public Health Center Cijagra Lama Bandung which was carried out in a training program and then supported by the placement of the OHS Policy in a meeting room or multipurpose so that every new employee or visitor can get information about the purpose of making the OHS policy as well as targets to be addressed by the Public Health Center Cijagra Lama Bandung.

The OHS activity plan has also been prepared for later implementation by the OHS Implementing Team or Manager. The OHS plan at the Public Health Center Cijagra Lama Bandung was made by considering the results of the initial study, IBPR, statutory requirements and other regulations as well as taking into account the resources owned.

The OHS Management Team at the Public Health Center Cijagra Lama Bandung consists of personnel who are included in the clinical quality management structure. The team is tasked with managing the OHS plan with the scope of the objectives and targets for the implementation of SMK3, the priority scale for the implementation of OHS work programs that can be implemented to support the achievement of continuous improvement in clinical quality, efforts to control hazards, determination of OHS program implementing resources and the implementation period accordingly. indicators of achievement and includes a system of accountability for the implementation of these OHS programs.

\section{Introduction of Potential Hazards and Risk Control}

Public Health Center Cijagra Lama Bandung has carried out hazard identification, risk assessment and control (IBPR). This IBPR has been included in the preparation of the OHS plan, where this plan is prepared and determined by the OHS management team referring to the Health Center OHS policy. Hazard identification is carried out by paying attention to several things, namely:

1. actions and conditions that can cause harm, and

2. types of KK and PAK that may occur.

The results of the hazard identification are used to then carry out a risk assessment to determine the priority of control over the risk level of the KK and PAK. Control measures for risk are carried out in accordance with the hierarchy of control efforts through technical, administrative and use of PPE.

\section{Table 2}

\section{Recording and Reporting of OHS Implementation at the Public Health Center Cijagra Lama Bandung}

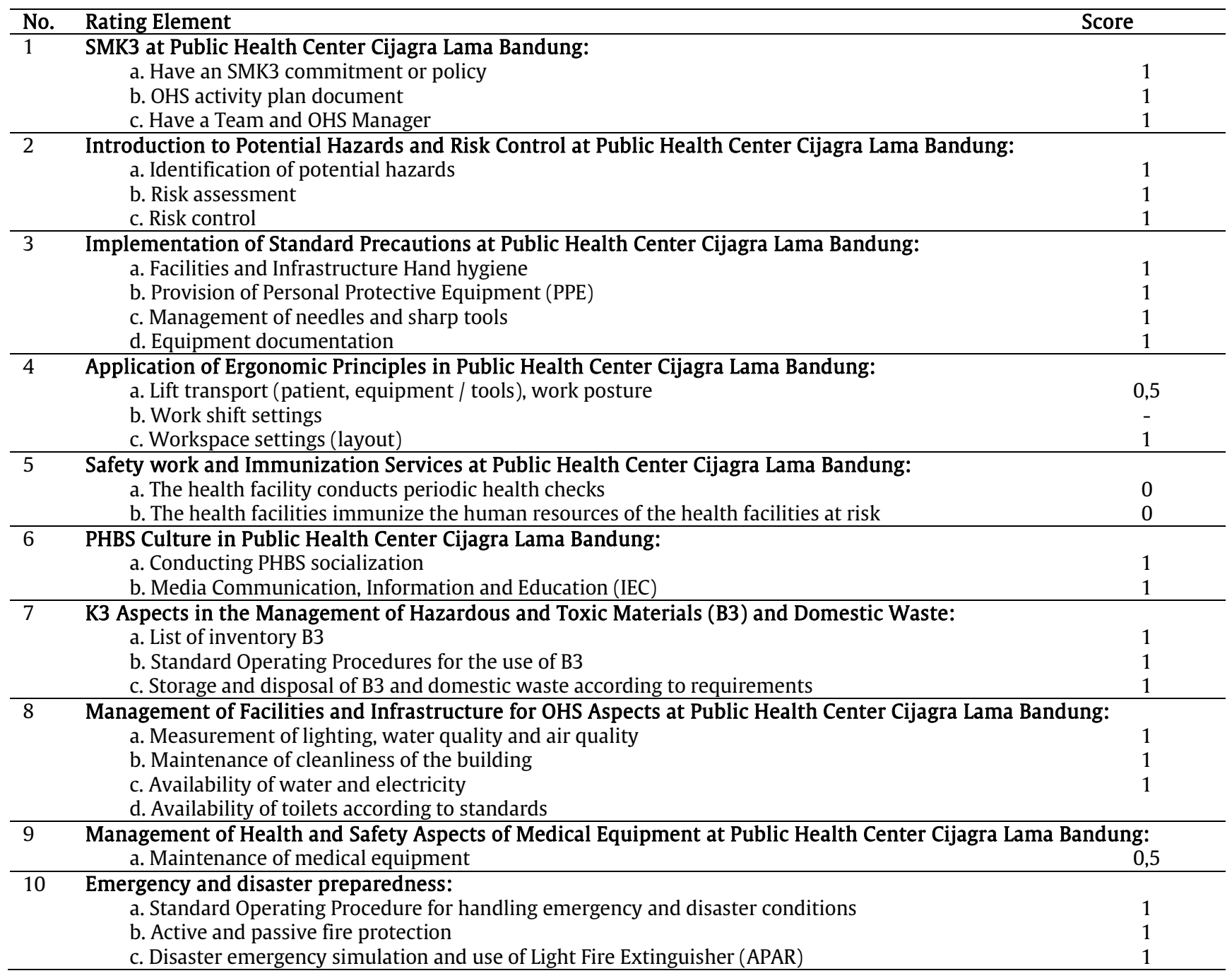




\begin{tabular}{ll}
\hline $11 \quad \begin{array}{l}\text { Training: } \\
\text { a. OHS trained health facilities human resources } \\
\text { b. Number of health facilities trained in OHS }\end{array}$ & 0,5 \\
& 0,5 \\
\hline Total Score & 0,8 \\
\hline Index & \\
\hline Note: & \\
Valuing score: & \\
$0 \quad:$ appraisal items have not been implemented \\
$0,5 \quad:$ new appraisal items were partially implemented \\
$\quad:$ not applicable item \\
Index calculation $=\frac{\text { Nilai Score }}{\text { Maximum Item Value amount }}$ \\
\hline
\end{tabular}

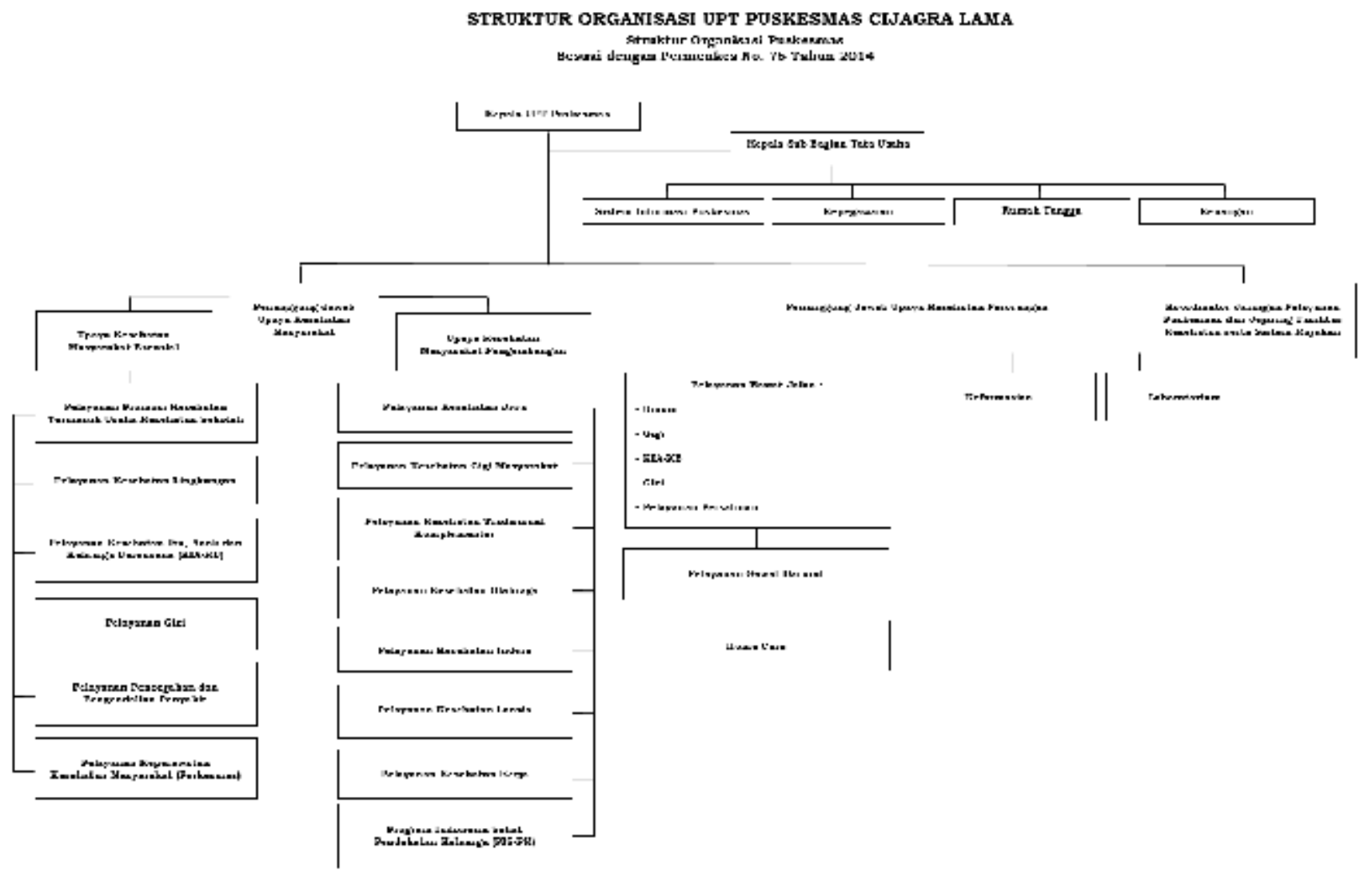

Figure 1

Organizational Structure at Public Health Center Cijagra Lama Bandung

Technical or engineering control efforts include several stages, starting from the stages of elimination, substitution, isolation, ventilation, sanitation and hygiene. Apart from engineering, education and training are carried out as an effort to control a risk. Also includes incentives, motivation and rewards. Evaluation of the effectiveness of risk control can be done by evaluating through the implementation of internal and external audits, incident investigation and law enforcement.

\section{Application of Standard Precautions}

The application of standard precautions at the Puskesmas Cijagra Lama Bandung is carried out through:

a. Provision of adequate hand washing facilities and infrastructure to prevent cross infection,

b. Use of proper and appropriate PPE,

c. Management of needles and sharp tools, and

\section{d. Equipment documents.}

The application of standard precautions mentioned above has been carried out in accordance with the provisions of laws and regulations. And for medical equipment documentation is easy to find, provides benefits and very easy to understand.

\section{Application of Ergonomic Principles}

The application of ergonomic principles at the Public Health Center Cijagra Lama Bandung for transportation has not been implemented for all work activities. Ergonomics principles are applied for manual lifting. But sometimes the implementation still doesn't pay attention to the weight of the goods and work posture. Other lifting and transportation activities are very rarely carried out, this is because there are no patient services that require lifting procedures, and there 
are no other transport activities that require more in-depth attention to the application of ergonomics.

Public Health Center Cijagra Lama Bandung does not operate for $1 \times 24$ hours, so there is no work shift arrangement. The workspace layout arrangement has met the requirements and got even better after the health facilities underwent a renovation of buildings and spaces in 2018 to 2019.

\section{Occupational Health and Immunization Services}

Public Health Center Cijagra Lama Bandung does not yet have a complete kesja (safety work) service program. Kesja examination only includes laboratory tests. The examination only consists of checking blood haemoglobin $(\mathrm{Hb})$, blood sugar levels, blood cholesterol and uric acid. The examination was carried out independently by the internal laboratory health personnel of the Public Health Center Cijagra Lama. Other laboratory tests include a triple elimination examination or commonly called $3 \mathrm{E}$ based on the Regulation of the Health Minister of the Republic of Indonesia Number 52 of 2017 concerning the elimination of transmission of Human Immunideficiency Virus (HIV), Syphilis and Hepatitis B from Mother to Child. Reagents for the $3 \mathrm{E}$ examination were provided by the Bandung City Health Office. As for the immunization, it has not been carried out on all employees of the Bandung Cijagra Lama Community Health Center.

The aforementioned matters are still not in accordance with and in line with the Decree of the Health Minister of the Republic of Indonesia No. 1087/2010. The forms of health services that need to be carried out include complete physical examinations, physical fitness, X-rays of the lungs where possible, routine laboratory examinations, other examinations deemed necessary, as well as appropriate examination to the need to prevent the hazards that are expected to arise especially for certain jobs.

The implementation of programs to improve physical health, mental condition and physical abilities of the personnel of Public Health Center Cijagra Lama Bandung which has been carried out is routine sports activities. This routine exercise is carried out every Friday morning before Public Health Center operating hours. Various types of sports are carried out alternately to accommodate the interests and personnel of these types of sports. The sports that are carried out include healthy heart exercises, Zumba exercises, pocopoco, and so on. The sports activities are also open to the general public who are in the operating environment of the health facilities.

\section{Culture of Clean and Healthy Living Behavior (PHBS)}

PHBS is a collection of behaviours that are practised based on awareness of learning outcomes and make a person or family able to help themselves in the health sector and play an active role in realizing public health (Ministry of Health, 2011).

In the health facilities, the primary target of PHBS is to practice behaviours that can make the health facilities behave in a clean and healthy life. The PHBS includes washing hands with soap (CTPS), use of healthy latrines, throwing garbage in the trash that has been provided, prohibiting smoking, not consuming narcotics, psychotropic substances and addictive substances (NAPZA), prohibiting spitting and throwing betel nuts in any place, eradication mosquito nests and larvae, and others.

Public Health Center Cijagra Lama Bandung has cultivated PHBS in accordance with applicable requirements and regulations. PHBS coaching at the health facilities includes the implementation of socialization. Also includes the use and utilization of communication, information and education (KIE) media coordinated by the Health Promotion Section (Promkes) which is aimed at not only all employees but also aimed at the community so that they can implement PHBS (Ministry of Health, 2013).

\section{K3 Aspects in the Management of Hazardous and Toxic Materials (B3) and Domestic Wastes}

The management of hazardous and toxic materials (B3) at the Public Health Center Cijagra Lama Bandung is in accordance with Government Regulation Number 74 of 2001. All B3 is carried out an inventory and documentation of records of use and disposal when it has expired. The use of B3 has a Standard Operating Procedure (SPO) to prevent KK.

The management of B3 waste at this health facility is carried out in accordance with Government Regulation Number 101 of 2014. B3 waste is classified according to its characteristics, then it is stored according to the storage time limit (Ministry of Environment and Forestry, 2014). Each type of B3 waste that has been recorded and stored in a special storage location for B3 waste is then given a symbol and label according to the nature and type of the waste (Ministry of Environment and Forestry, 2013).

In general, B3 waste management has been carried out in accordance with statutory regulations, namely Regulation of the Minister of Environment and Forestry Number P.56 / Menlhk-Setjen / 2015 concerning Procedures and Technical Requirements for Management of Hazardous and Toxic Waste from Health Service Facilities. The management of B3 waste at this health facility is coordinated by the Environmental Health Service Section by following the 2013 regulations regarding the implementation of environmental health services (Ministry of Environment and Forestry, 2013), although emergency programs for the management of B3 and or B3 waste have not been implemented properly (Ministry of Environment Life and Forestry, 2019). Thus, the Public Health Center Cijagra Lama Bandung must develop the emergency program so that it can be run properly and in accordance with applicable regulations.

The management of domestic waste in this health facility includes waste management and wastewater originating from toilet water or black water which contains pathogens from faeces that have the potential to cause environmental pollution. Then, there is another wastewater that comes from various domestic activities or greywater. In handling domestic waste, the Public Health Center Cijagra Lama collaborates with the local urban village office. Domestic waste that is collected at the temporary collection point (TPS) is then transported to be emptied according to the work schedule of environmental cleaners. This is part of the efforts to implement and foster community empowerment in the health sector. Handling for domestic waste in the form of black water and greywater is still carried out by simple processing in a septic tank unit which is regularly maintained because this health facility does not have a wastewater treatment plant (IPAL) which can also be used to handle liquid waste from laboratory service activities medical.

\section{Management of Facilities and Infrastructure for OHS Aspects}

K3 aspects management of facilities and infrastructure at the Public Health Center Cijagra Lama Bandung includes measurement of lighting (illumination), water quality and air quality. The management of this aspect follows the Regulation of the Minister of Health of the Republic of 
Indonesia Number 32 of 2013 concerning Implementation of Sanitarian Power Works. The results of measurements of lighting, water quality and air quality have met the standards and requirements (Ministry of Health, 2016; Ministry of Manpower, 2018).

Apart from the environmental factors mentioned above, maintenance of cleanliness of buildings, availability of water and electricity and toilets according to standards is still under the coordination of the Environmental Health Service Section. The staff of this section are part of the health care health and safety management team, which is tasked with regularly ensuring that cleaning services carry out building cleaning activities including public facilities such as toilets, prayer rooms, waiting rooms, cleaning and disinfection are always carried out.

The availability of clean water for the implementation of facility management must complete the water quality requirements for hygiene and sanitation activities for this health facility (Ministry of Health, Republic of Indonesia, 2017). Including the availability of electricity by equipping a diesel engine in the event of a power cut by the State Electricity Company. This is intended so that there is no health service for patients and visitors are stopped if there is no electricity supply.

\section{Medical Equipment Management}

Management of medical equipment in the form of supervision of the process of managing medical equipment in accordance with OHS aspects. This management activity also includes evacuation equipment, control equipment, personal protective equipment including PPE. The management contains procedures and information that need to be communicated to all health facilities personnel based on the results of the IBPR as well as sources of hazards which include the conditions and conditions of machines, tools, work tools (utensils), including inspection, calibration and maintenance of these facilities and infrastructure.

Findings of unsuitable conditions, such as damage, defects and malfunctions are recorded and then scheduled for a replacement if repairs cannot be made. Records of these conditions were documented by the OHS management team of the Public Health Center Cijagra Lama Bandung.

\section{Preparedness for Facing Emergency and Disaster Conditions}

Public Health Center Cijagra Lama Bandung has preparedness to face emergencies and disasters. This emergency condition also includes a fire incident. This preparedness planning is carried out through:

a. Identification of risks for emergencies and disasters.

b. Disaster vulnerability risk analysis.

c. Emergency or disaster risk mapping.

d. Emergency and disaster control.

SPO for handling emergencies and disasters has been socialized to all employees at Public Health Center Cijagra Lama Bandung, including patients and visitors. SPO is available and accessed by all who are in the health facility. Evacuation plans and routes are very communicative, making it easier to gather at the assembling point in case of emergencies and disasters.

Active and passive fire protection at Public Health Center Cijagra Lama has been implemented well. All personnel understand that fires in the workplace have very detrimental consequences for both health facilities, workers and national development interests (Ministry of Manpower, 1999). Based on the results of interviews about fire management at this health facility, the Public Health Center has conducted outreach to all workers on how to handle fires. The socialization was given and explained directly from the Bandung City Fire Service (DAMKAR). The socialization is carried out every 2 (two) years. The socialization includes a light fire extinguisher (APAR) and procedures for its use to avoid fire, detection and control of smoke and fire (smoke detectors), alarm systems, automatic sprinklers, emergency exits, evacuation routes and procedures. , emergency stairs, safe assembly points (assembling points), water sprayers (hydrant), and the formation of a fire fighting team as well as training and socialization.

This is in line with the Health Minister Regulation of the Republic of Indonesia Number 66 at 2016. Fire prevention and control aim to ensure that human resources (HR), patients and their companions, visitors, and health facilities assets are safe from the dangers of fire, smoke and other materials.

\section{Training}

The implementation of the health facility HR training program on OHS has been implemented. However, based on the results of interviews regarding OHS training, not all of the human resources that have been attended are, only the Head of the OHS Management Team and personnel selected by the Health Office have participated. And for the follow-up training carried out at this health facility, which is made for all Public Health Center personnel, it is limited to IBPR, standard precautions, PHBS and preparedness to face emergencies and disasters.

This has not fulfilled the goals and objectives regarding job training because it does not meet the competence of the human resources of the health facilities. Training is held and directed to equip, improve and develop work competencies in order to increase capability, productivity and welfare (Law Number 13, 2003). Public Health Center Cijagra Lama has planned that in the coming years all existing personnel will take part in training related to health and safety health services. This is because OHS has become an absolute necessity and condition to create a healthier and safer work quality.

\section{Conclusions and Recommendations}

The effectiveness and suitability of SMK3 health facilities to be sustainable to achieve the goals of SMK3 at Puskesmas Cijagra Lama Bandung has an index of 0.8 or $80 \%$ that meets the requirements according to the Regulation of the Indonesian Minister of Health Number 52 of 2018 concerning Occupational Safety and Health in Health Service Facilities.

OHS performance improvements and enhancements were carried out for elements that were still unsuitable, which consisted of:

1. Application of ergonomic principles for transportation;

2. Regular human resource health checks;

3. Immunization for human resources of health facilities at risk;

4. Maintenance of medical equipment;

5. OHS trained human resources for health facilities, and

6. The number of health care personnel trained in OHS.

The results of the SMK3 evaluation are expected to overcome the implications of OHS implementation on all 
activities and performance of the Health Service. Several things can be done to improve OHS performance so that the implementation of SMK3 at the Public Health Center Cijagra Lama Bandung can be even better, including:

1. Education and training on the application of ergonomic principles, especially for transport work;

2. Planning and implementing regular human resource health checks which can be facilitated by the Health Office;

3. Providing immunization for human resources of health facilities at risk;

4. Carry out periodic maintenance and replacement of medical equipment if repairs cannot be made;

5. Conduct OHS training for health facilities human resources which can be carried out by trained facilitators or health facilities personnel who have received previous training; and

6. Increasing the number of health care personnel trained in OHS who can be carried out regularly and in rotation so that all human resources have knowledge of OHS and can apply it at the health facility.

Apart from the foregoing, the implementation of recording and reporting can be improved. Health Minister Regulation of the Republic of Indonesia Number 52 of 2018 states that every health facility is obliged to record and report on the implementation of OHS. The OHS recording and reporting activities are carried out every semester and annually. In order to improve performance, several things must be considered, namely:

1. Changes in-laws and Government regulation of the Republic of Indonesia;

2. Demands from related parties, such as the Health Office, Local Government, Central Government and others;

3. Changes in the organizational structure of the health facilities;

4. Development of science, technology and arts (IPTEKS);

5. Results of the KK and PAK assessments;

6. Suggestions from related parties, such as patients and their companions, visitors and including the general public around the operating health facilities.

\section{Acknowledgement}

Thank you to dr. Tita Rostiana as the Head of the Public Health Center Cijagra Lama Bandung who has given permission. Then, to all employees and health workers at the Public Health Center Cijagra Lama Bandung who have helped the author in conducting this research.

\section{References}

Dinas Kesehatan Kota Bandung. (2019). Laporan Penyelenggaraan K3 di Puskesmas Cijagra Lama. Bandung.

Kementerian Kesehatan. (2013). Peraturan Menteri Kesehatan Republik Indonesia Nomor 65 Tahun 2013 tentang Pedoman Pelaksanaan dan Pembinaan Pembedayaan Masyarakat Bidang Kesehatan. Retrieved from http://promkes.kemkes.go.id/permenkes-no65-tahun-2013tentang-pedoman-pelaksanaan-dan-pembinaanpemberdayaan-masyara

Kementerian Kesehatan. (2016). Peraturan Menteri Kesehatan Republik Indonesia Nomor 70 Tahun 2016 tentang Standar dan Persyaratan Kesehatan Lingkungan Kerja Industri. Retrieved from http://www.kesjaor.kemkes.go.id/documents/PMK_No._70_ ttg_Standar_Kesehatan_Lingkungan_Kerja_Industri_.pdf

Kementerian Kesehatan RI. (2004). Keputusan Menteri Kesehatan RI Nomor 128/MENKES/SK/II/2004 Tentang Kebijakan Dasar Pusat Kesehatan Masyarakat. Retrieved from https://m.hukumonline.com/pusatdata/detail/18571/nprt/lt 50ed1b1582b99/keputusan-menteri-kesehatan-no128_menkes_sk_ii_2004-tahun-2004-kebijakan-dasarpusat-kesehatan-masyarakat

Kementerian Kesehatan RI. (2011). Peraturan Menteri Kesehatan Republik Indonesia Nomor 2269/Menkes/Per/XI/2011 tentang Pedoman Pembinaan Perilaku Hidup Bersih dan Sehat. Retrieved from https:/peraturan.bkpm.go.id/idih/userfiles/batang/PMK No. 65 ttg Pemberdayaan Masyarakat Bidang Kesehatan.pdf

Kementerian Kesehatan RI. (2013). Peraturan Menteri Kesehatan Republik Indonesia Nomor 32 Tahun 2013 tentang Penyelenggaraan Pekerjaan Tenaga Sanitarian. Retrieved from http://hukor.kemkes.go.id/uploads/produk hukum/PMK No. 13 ttg Pelayanan KESLING di Puskesmas.pdf

Kementerian Kesehatan RI. (2015). Peraturan Menteri Kesehatan Republik Indonesia Nomor 13 Tahun 2015 tentang Penyelenggaraan Pelayanan Kesehatan Lingkungan di Puskesmas. Retrieved from http://hukor.kemkes.go.id/uploads/produk hukum/PMK No. 13 ttg Pelayanan KESLING di Puskesmas.pdf

Kementerian Kesehatan RI. (2016). Peraturan Menteri Kesehatan Republik Indonesia. Nomor 66 Tahun 2016 tentang Keselamatan dan Kesehatan Kerja di Rumah Sakit. Retrieved from http://www.kesjaor.kemkes.go.id/documents/PMK No. 66 ttg_Keselamatan_dan_Kesehatan_Kerja_Rumah_Sakit_pdf

Kementerian Kesehatan RI. (2017). Peraturan Menteri Kesehatan Republik Indonesia Nomor 52 Tahun 2017 tentang Eliminasi Penularan Human Immunideficiency Virus, Sifilis, dan Hepatitis B dari Ibu ke Anak. Retrieved from https://www.persi.orid/images/regulasi/permenkes/pmk52 2017.pdf

Kementerian Kesehatan RI. (2019). Peraturan Menteri Kesehatan RI Nomor 43 Tahun 2019 tentang Pusat Kesehatan Masyarakat. Retrieved from https://dinkes.tasikmalayakota.go.id/images/download/Per menkes No.43 Tahun 2019.pdf

Kementerian Ketenagakerjaan. (2018). Peraturan Menteri Ketenagakerjaan Nomor 5 Tahun 2018 tentang Keselamatan dan Kesehatan Kerja dan Lingkungan Kerja. Retrieved from https://jdih.kemnaker.go.id/data puu/Permen 5 2018.pdf

Kementerian Lingkungan Hidup dan Kehutanan. (2001). Peraturan Pemerintah Republik Indonesia Nomor 74 Tahun 2001 tentang Pengelolaan Bahan Berbahaya dan Beracun. Retrieved from http://ditjenpp.kemenkumham.go.id/arsip/ln/2001/PP742001.pdf

Kementerian Lingkungan Hidup dan Kehutanan. (2013). Peraturan Menteri Lingkungan Hidup Nomor 14 Tahun 2013 tentang Simbol dan Label Limbah Bahan Berbahaya dan Beracun. Retrieved from http://gakkum.menlhk.go.id/assets/fileperaturan/Permen_L H_14_th_2013_Simbol_Label_B3.pdf

Kementerian Lingkungan Hidup dan Kehutanan. (2014). Peraturan Pemerintah Republik Indonesia Nomor 101 
Tahun 2014 tentang Pengelolaan Limbah Bahan Berbahaya dan Beracun. Retrieved from https://m.hukumonline.com/pusatdata/detail/lt5493ed2d05 c77/node/515/peraturan-pemerintah-nomor-101-tahun2014

Kementerian Lingkungan Hidup dan Kehutanan. (2015). Peraturan Menteri Lingkungan Hidup dan Kehutanan Nomor P.56/Menlhk-Setjen/2015 tentang Tata Cara dan Persyaratan Teknis Pengelolaan Limbah Bahan Berbahaya dan Beracun dari Fasilitas Pelayanan Kesehatan. Retrieved from

http://ditjenpp.kemenkumham.go.id/arsip/bn/2016/bn5982016.pdf

Kementerian Lingkungan Hidup dan Kehutanan. (2019). Peraturan Menteri Lingkungan Hidup dan Kehutanan Nomor 74 Tahun 2019 tentang Program Kegawatdaruratan Pengelolaan Bahan Berbahaya dan Beracun dan/atau Limbah Bahan Berbahaya dan Beracun. Retrieved from http://jdih.menlhk.co.id/uploads/files/P_74_2019_KEDARUR ATAN_B3_menlhk_11112019091007.pdf

Kementerian Lingkungan Hidup dan Kehutanan. (2020). Peraturan Menteri Lingkungan Hidup dan Kehutanan Republik Indonesia Nomor P.12/MENLHK/SETJEN/PLB.3/5/2020 tentang Penyimpanan Limbah Bahan Berbahaya dan Beracun. Retrieved from http://jdih.menlhk.co.id/uploads/files/P 122020 PENYIMP ANAN_LIMBAH_B3_menlhk_06262020092441.pdf

Kementerian Tenaga Kerja. (1996). Peraturan Menteri Tenaga Kerja Nomor 5 Tahun 1996 tentang Sistem Manajemen Keselamatan dan Kesehatan Kerja. Retrieved from https://jdih.kemnaker.go.id/data wirata/1997-1-2.pdf

Kementerian Tenaga Kerja. (1999). Keputusan Menteri Tenaga Kerja Republik Indonesia Nomor 186 Tahun 1999 tentang Unit Penanggulangan Kebakaran di Tempat Kerja. Retrieved from https://jdih.kemnaker.go.id/data wirata/1999-3-2.pdf

Kementerian Tenaga Kerja. (2012). Peraturan Pemerintah No. 50 Tahun 2012 Tentang Penerapan Sistem Manajemen Keselamatan dan Kesehatan Kerja. Retrieved from https://jdih_kemnakergo.id/data_wirata/2012-3-1.PDF

Menteri Kesehatan Republik Indonesia. (2018). PERATURAN MENTERI KESEHATAN REPUBLIK INDONESIA NOMOR 52 TAHUN 2018 TENTANG KESELAMATAN DAN KESEHATAN KERJA DI FASILITAS PELAYANAN KESEHATAN. Jakarta, Indonesia: MENTERI KESEHATAN RI.

Sugiyono. (2011). Metode Penelitian Pendidikan (Pendekatan Kuantitatif, Kualitatif, dan $R \& D$ ). Bandung: Alfabet.

Suma'mur. (1986). Keselamatan Kerja dan Pencegahan Kecelakaan. Jakarta: Gunung Agung.

Undang-Undang Nomor 13. (2003). Undang-Undang Republik Indonesia Nomor 13 Tahun 2003 tentang Ketenagakerjaan. Retrieved from https://www.hukumonline.com/pusatdata/detail/13146/un dangundang-nomor-13-tahun-2003

Wijayantiningrum, T. (2019). Analisis Mutu Upaya Kesehatan Perseorangan Pasca Penilaian Akreditasi di Puskesmas Wilayah Kota Semarang Tahun 2019. Universitas Negeri Semarang. Retrieved from https:/lib.unnes.ac.id/35256/1/UPLOAD TUTUK WIJAYANT ININGRUM1.pdf 